\title{
Strategiczne węzły miejskie w wielkich miastach Azji Południowo-Wschodniej
}

\section{Dariusz Gawel}

Samodzielna Pracownia Architektoniczna, Wydział Budownictwa i Architektury, Politechnika Lubelska, e-mail:d.gawel@pollub.pl

Streszczenie: Celem pracy - jest charakterystyka przestrzeni publicznej w ośrodkach Azji Południowo -Wschodniej ${ }^{1}$ na tle współczesnych problemów rozwoju wielkich miast. Poprzez węzły miejskie autor dokonuje analizy centrum w strategicznych ośrodkach tego regionu.

W dzisiejszych czasach tworzenie nowych trendów miastotwórczych uległo ograniczeniu na kontynencie europejskim (tu wiodącym pozostaje - proces rewitalizacji) przenosząc się do Azji i Afryki, gdzie na naszych oczach kreowane są ogromne nowe kwartały i miasta (często w sposób gwałtowny i niezmiernie szybki).

Poruszane problemy w artykule odnoszą się do sposobu kształtowania struktury przestrzeni publicznych wielkich miast, obejmującej nowe zjawiska urbanistyczne, które funkcjonują na tle znanych i zdiagnozowanych zjawisk jak metropolizacja czy globalizacja.

Strategiczne elementy struktury metropolitarnej wielkich miast azjatyckich są niejednokrotnie przyczynkiem do tworzenia nowych niezależnych dzielnic - regionów wpływających na podziały i fragmentaryzację samej przestrzeni publicznej, a w konsekwencji na wyodrębnienie niezależnych ośrodków.

Słowa kluczowe: węzły strategiczne, przestrzeń publiczna, wielkie miasta, Azja Południowo-Wschodnia, metropolizacja, globalizacja.

\section{Wstęp}

Człowiek w swojej ewolucji szybko zaakceptował korzyści wynikające z życia w mieście. Migracje społeczne ze wsi do miast stały się istotnym czynnikiem w kolejnych fazach rozwoju ośrodków osadnictwa. Tworzone przez wiele wieków środowisko miejskie musiało posiadać nie tylko walory estetyczne, ale również funkcjonalne, zarówno pod względem przestrzennym (poprzez zapewnienie odpowiedniej warunków obronności, skali, dostępu czy odległości zabudowy) jak i organizacyjnym (tworzenie w oparciu o instrumenty prawne i nakreślenie ram gospodarowania).

Dzisiaj wiele $\mathrm{z}$ tych podstawowych cech uległo przeobrażeniu tworząc skomplikowany organizm wielu zależności wyrażanych poprzez status administracyjny oraz sposób zorganizowania struktury urbanistycznej.

Nie można zapomnieć o człowieku jako podmiocie struktury urbanistycznej. Miasto zostało tworzone przez człowieka i dla niego żyje. To człowiek nadaje sens funkcjonowania

1 Azja Południowo-Wschodnia - jest regionem obejmującym Płw. Indochiński, Archipelag Malajski i Filipiny. Pod względem rozwoju gospodarczego teren ten jest bardzo zróżnicowany. W krajach regionu znajdują się jedne z największych miast kontynentu azjatyckiego jak Bangkok czy Jakarta. Z uwagi na szybkie tempo rozwoju ekonomicznego tereny te stanowią obok Azji Wschodniej i Południowej przykład postępujących zjawisk wzrostu społecznego, gospodarczego, rolnictwa, przemysłu i postępu technicznego. 
przestrzeni miejskiej będąc najistotniejszym czynnikiem jej struktury. Sposób percepcji struktury miejskiej wyraża się w jej strukturze społecznej. Chyba najlepszym przykładem zobrazowania tej struktury jest definiowanie i organizacja samej przestrzeni zurbanizowanej. Jej powszechnym przykładem staje się jej hierarchizacja, na prywatną, grupową i publiczną.[1]. Dlatego powiązanie walorów społecznych i kulturowych w środowisku miejskim jest jego ponadczasową wartością. Adekwatnym wydaje się tu stwierdzenie, iż „w tradycyjnym mieście przestrzeń publiczną tworzy labirynt ulic i placów, układających się w sekwencje i hierarchiczną spójną całość nasyconą znaczeniem społecznym.” [3] s. 34.

Stwierdzenie to jest o tyle istotne że podkreśla społeczną rolę przestrzeni, której nie należy odbierać jako słabo zdefiniowaną czy podporządkowaną warunkom miejsca. Nie ulega wątpliwości iż przestrzeń publiczna², jawi się jako obszar o szczególnym znaczeniu dla zaspokajania potrzeb mieszkańców, poprawy jakości ich życia i sprzyjający nawiązywaniu kontaktów społecznych (ze względu na jego położenie oraz cechy funkcjonalno-przestrzenne).

\section{Problemy rozwoju wielkich miast}

We współczesnym świecie obserwujemy dokonującą się na naszych oczach gwałtowną, czasami niekontrolowaną (szczególnie w warunkach azjatyckich i afrykańskich) urbanizację. Następuje wielkie powszechne współdziałanie procesów politycznych, społecznych, kulturowych i ekonomicznych. Kolejną siłą napędową wielu zjawisk globalnych staje się postęp naukowy, a w szczególności rozwój nauk informatycznych i telekomunikacyjnych. Komunikacja (w szerokim ujęciu) wraz ze wzrostem świadomości społecznej, ludności globu stała istotnym czynnikiem migracji ludności [6]. Współczynnik skolaryzacji (w poszczególnych przedziałach wiekowych szkoły podstawowej, średniej i wyższej ${ }^{3}$ ) nie tylko w Polsce, ale na całym świecie uległ istotnemu wzrostowi. To przy wysokiej stopie bezrobocia zmusza do migracji ekonomicznej. Nie dziwią już kolejne rekordy wzrostu liczby mieszkańców i przeludnienie miast. Ludzie nie widzą dla siebie przyszłości w wolniej rozwijających małych ośrodkach. Stąd współczesne miasto jawi się jako miejsce o walorach szczególnych, stanowiące przestrzeń życiową, gdzie spełniają się wszystkie marzenia związane $\mathrm{z}$ bezpieczeństwem ekonomicznym i dobrobytem jego mieszkańców.

Większość współczesnych procesów rozwojowych oparta jest o globalną współzależność gospodarczą i przemysłową, Dążenie do stworzenia ogromnej przestrzeni życiowej zaczyna jawić się, jako zagrożenie tożsamości społecznej i kulturowej. Jest to szczególnie niebezpieczne w przypadku braku możliwości wpływania na niektóre procesy szczególnie te związane z rozwojem gospodarczym w danym regionie. Gwałtowny niekontrolowany przepływ kapitałów i wzrost nierówności społecznej ${ }^{4}$, nie są w stanie wpłynąć na zmianę tych trendów globalnych [6].

Według Jałowieckiego ,globalizację charakteryzują cztery równoległe zjawiska: przepływ kapitału, informacji, umiędzynarodowienie rynku pracy, powodujące, że siła robocza staje się zasobem światowym, oraz rozwój ponadnarodowych korporacji, podejmujących

\footnotetext{
2 Obwieszczenie Marszałka Sejmu Rzeczypospolitej Polskiej z dnia 13 maja 2016 r. w sprawie ogłoszenia jednolitego tekstu ustawy o planowaniu i zagospodarowaniu przestrzennym (Dz. U. z 2016 r. poz. 778).

3 Dane GUS - współczynnik skolaryzacji netto w szkolnictwie wyższym Polski rósł - odpowiednio z 9,8\% w 1990/1991 roku do 40,8\% w 2010/2011 roku, zaś w roku akademickim 2015/16 spadł do 37,3\%, w przypadku szkół podstawowych wynosi on prawie $100 \%$.

${ }_{4}^{4}$ Pod koniec XX wieku, najbiedniejsze 20\% ludności świata miała dochody ponad 70 razy mniejsze od 20\% najbogatszej części globu. s. 91-96
} 
decyzje zgodnie z własną strategią, mającą doniosłe skutki dla gospodarek wielu krajów, które nie mają na nie niemal żadnego wpływu” [8] s. 11.

Coraz częściej w wyniku globalizacji dochodziło do nierównomiernego rozwoju przestrzennego miast. Miasta duże stawały się ośrodkami wielofunkcyjnymi (multifunkcyjnymi) i jeszcze większymi. Miasta małe w wyniku tego procesu zatrzymywały się w rozwoju, tracąc w ten sposób znacznie swój potencjał ekonomiczny zasilający ośrodek centralny.

Według Węcławowicza globalizacja, stanowiąca zjawisko społecznie negatywne wpłynęła na kształtowanie przestrzeni. Jako miejsce wymiany gospodarczej na szeroką skalę globalizacja spowodowała szybki, czasami gwałtowny wzrost miast. Mówiąc inaczej wielkie miasta stały się jeszcze bardziej wielkie, generując różnice społeczne (dysproporcja rozwoju różnych fragmentów i dzielnic), a jednocześnie ograniczając samą przestrzeń życiową. W konsekwencji mamy do czynienia z miastem globalnym, konkurującym ośrodkiem bez indywidualnych cech, z dzielnicami dla ubogich, oraz jeszcze bardziej rozlewającymi się dzielnicami nędzy [14].

Zespół przyległych mniejszych ośrodków funkcjonujących w obrębie oddziaływania (najczęściej odległość ta sprowadza się do kilku rzadziej kilkudziesięciu kilometrów). Wg Kriera miasto nie może rosnąć bez utraty swojej tożsamości. Tak jak ludzka rodzina, miasto rośnie poprzez reprodukcję, czyli zwielokrotnienie. Co może oznaczać takie podejście - tylko jedno policentryzm [9]. Poszukiwanie zależności pomiędzy ośrodkami wydaje się budować konflikty o znaczeniu prestiżowym.

Połączenie ich w sieć zależności pozwala na wytworzenie nowego tworu struktury osadniczej. Wytworzona w ten sposób zależność ekonomiczno-przestrzenna stała się podstawą do wykształcenia aglomeracji miejskich.

W przypadku większości wielkich miast termin aglomeracja nie jest adekwatny do formy osadniczej jaką tworzą. Łączenie się aglomeracji w wielomilionowe zespoły osadnicze zostały określone jako megalopolis. Podstawą do tworzenia ciągłych układów osadniczych jest rozszerzająca się strefa obrzeżna miast z zabudowa mieszkaniowa wielo- i jednorodzinną. (rozlewanie się miast) [5]. Powiązania przestrzenne aglomeracji istnieją dzięki sieci dobrze zorganizowanej komunikacji.

Jednak może się tak zdarzyć iż więzi gospodarcze pomiędzy ośrodkami będą na tyle słabe, lub dojdzie do zjawisk odwrotnych, czyli wyłonienia się głównego ośrodka - metropolii, co spowoduje pogłębieniem dysproporcji przestrzennych, a tym samym dominacją tegoż ośrodka - centrum. Metropolizacja jako proces staje ze wszech miar istotna $\mathrm{z}$ uwagi na czynniki społeczne związane $\mathrm{z}$ mieszkańcami regionu i ich poczuciem przynależności. „Metropolizacja jest więc procesem społecznym o kardynalnym znaczeniu zarówno w sensie poznawczym, jak i praktycznym. Jej adekwatne poznanie staje się warunkiem racjonalnej polityki społecznej w skali państwa, regionów i samych metropolii” [2] s. 28.

\section{Punkty strategiczne jako czynniki kształtowania współczesnych centrów wielkomiejskich}

Jako podstawę do zdefiniowania terminu „węzeł miejski” należy przyjąć określenie K. Lyncha [10] z 1960 roku, który opisując specyfikę tego miejsca wykorzystuje elementy urbanistyczne, jak: droga - ścieżka - krawędź - węzeł - punkt orientacyjny - dzielnica. Zastosowana hierarchia prowadzi nas od detalu w postaci ścieżki, do ogółu jakim jest mnogość elementów w konkretnym miejscu - dzielnicy. Definicja ta staje się niepełna poprzez brak czynnika społecznego - ludzkiego. Człowiek tutaj nie istnieje. 
Około 30 lat później Wejchert [15] nakreślił wizję punktów węzłowych jako istotnych elementów krajobrazu miejskiego. Jego podejście było skrajnie rożne - nasycone czynnikami społecznymi i cechami miejsca. Miały być one charakteryzowane poprzez takie elementy jak:

1. człowiek (poruszający się) będący w ruchu, pozostający nieodłącznym elementem specyfiki miejsca,

2. dynamiczny obraz - jako pozorna ruchomość przestrzeni dookoła (będąca wynikiem postrzegania jej),

3. indywidualne cechy miejsca (np. wynikające z cech historyczno-kulturowych),

4. czytelność formy, barwa lub inne cechy znaków szczególnych (budynków, tras komunikacyjnych, reklam lub innych obiektów funkcjonujących w przestrzeni),

5. spójność cech miejsca z cechami krajobrazu miasta.

W ówczesnych czasach była to wizja mało realna w warunkach polskich. Polska nie była jeszcze na tym etapie rozwoju gospodarczego. Dziś kiedy tego typu miejsca pojawiają się w naszym sąsiedztwie, możemy dokonać ich dokładniejszej oceny.

Punkty węzłowe stanowią często, złożone układy przestrzenne. Ich funkcjonowanie opiera się obecnie na łączeniu komunikacji z przestrzenią publiczną i wieloelementowym środowiskiem zbudowanym obiektów architektonicznych. Węzły komunikacyjne w obrębie wielkich miast posiadają nie mniejsze znaczenie jako element infrastruktury, niż kształtowana wokół architektura. Stąd podkreślenie ich dużego znaczenia.

W nn pracy, autor często posługuje się zamiennie terminami węzły centralne, punkty węzłowe lub węzły integracyjne i strategiczne, wszystkie one odnoszą się do tych samych istotnych definiowanych miejsc. Znaczenie ich określał Zuziak twierdząc ,„pojęciu węzeł odpowiadają różne terminy i koncepcje badawcze stosowane w analizach regionalnych, teorii urbanistyki i praktyce planowania i projektowania urbanistycznego. Mamy tu takie hasła jak: miejsce centralne, węzły integracyjne, ogniska /skupiska aktywności, ośrodki koncentracji infrastruktury społecznej, węzły strategiczne interwencji, węzły innowacyjności, koncentratory, traktory, strategiczne węzły metropolitarne itp. terminy te pojawiają się w różnych konfiguracjach i kontekstach zarówno w dokumentach planistycznych wyrażających politykę przestrzenną na szczeblu regionalnym i lokalnym, jak i w studiach i badaniach poświęconych przestrzennym strukturom metropolitarnym, zwłaszcza w pracach na temat policentryczności europejskich struktur osadniczych (np. projekty ESPON)" [16] s.45.

Poza Europą Zachodnią czy miastami w Ameryce Płn. to kontynent azjatycki zaczęto szybko postrzegać jako współczesne pole doświadczalne tworzenia nowoczesnej przestrzeni publicznej i rozwoju nowych technologii. Poprzez swój rozwój gospodarczy w dzisiejszych czasach Azja stała się kontynentem szybkich procesów urbanistycznych w warunkach postępującej gwałtownie urbanizacji. Przytoczone przykłady azjatyckie, mogą obrazować możliwości kształtowania centrów i ich znaczenie w procesie organizacji struktury miasta.

Pod względem przestrzennym miasto wytworzyło wiele lokalnych węzłów strategicznych, związanych zasadniczo z krzyżowaniem się istotnych arterii komunikacyjnych. Dodatkowym atrybutem tych miejsc jest zabudowa wysokościowa. Często stworzona jeszcze w minionych czasach. Obiekty takie pozbawione są cech miejsca, bez możliwości kształtowania otoczenia tworzącego wzajemne powiązania elementów w wytworzonym środowisku. Adekwatne wydają się tutaj słowa definiujące wzajemne relacje pomiędzy formą, bryłą, materiałem i ładem przestrzennym otoczenia. „mówiąc o środowisku musimy tez wyrazić zgodę na to, że nie jest naszym zadaniem kształtowanie tylko budynku, ale szerszego otoczenia, którego budynek stanowi jedynie część. Środowisko przestrzenne powstaje nie w próżni, lecz w określonej rzeczywistości społecznej i kulturowej. Jego forma powinna zatem wynikać z uwarunkowanych przez kulturę społeczną wyobrażeń i aspiracji - rolą architekta jest ich 
stałe rozpoznawanie i poszukiwanie ich wyrazu przestrzennego. Musimy tym samym zgodzić się, że ani przeznaczenie użytkowe, ani materiał budowlany, metody konstrukcji, ilość zainwestowanych pieniędzy czy wreszcie oryginalność pomysłu same przez się nie nadają budowli rangi,,dzieła architektury”. W hierarchii celów oryginalność pomysłu ustąpić musi harmonii tworzonego środowiska." [11] s. 16.

Sytuacja taka jest szczególnie ważna w miejscach o charakterze historycznym, gdzie kontekst lokalizacji odgrywa istotną rolę jako przestrzeń o wartościach kulturowo - społecznych, połączonych z walorami przyrodniczo artystycznych [13].

\section{Centrum wielkiego miasta - analiza wybranych przykładów}

Bardzo często dokonywana ocena miasta następuje poprzez jego centrum. To tutaj w tysiącach połączeń zależności struktury przestrzennej doświadczamy indywidualnych odczuć ludzkich. Zaczynamy klasyfikować i oceniać zarówno elementy fizjonomii jak i ładu przestrzennego. W szybki sposób zaczynamy postrzegać miasto poprzez jego centrum i zaplecze w postaci dzielnic- kwartałów o mniejszej intensywności zabudowy.

Wytworzony schemat układu miasta składający się ze centrum i okolicznych dzielnic, w obrębie strefy pośredniej nie ma bezpośredniego odniesienia do miast azjatyckich. Na skutek szybkiego rozwoju miasta te pozbawione są niejednokrotnie dzielnic historycznych (ograniczając się sporadycznie do pojedynczych obiektów). Na przykładzie tych miast można prześledzić postępującą monofunkcyjność dzielnic lub całych niezależnych ośrodków w obrębie aglomeracji. Możliwe jest to dzięki wytworzonym centrom lokalnym, ich charakter opiera się na usługach podstawowych i ponadpodstawowych. (mieszkaniowe, biurowe, przemysłu elektronicznego czy uniwersyteckie).

Jako materiał analityczny do porównań posłużyły tutaj miasta azjatyckie tworzące rozwinięte sieci aglomeracji, a w przypadku niektórych z nich można mówić o formach megalopolis 5 .

Tabela 1. Uwarunkowania geograficzne - charakterystyka miast, porównanie wybranych ośrodków azjatyckich - lokalizacja, skala, specyfika miejsca, demografia. (opracowanie własne)

\begin{tabular}{|c|c|c|c|c|c|c|c|}
\hline Lp. & Państwo & Miasto & $\begin{array}{l}\text { Charakterystyka } \\
\text { lokalizacyjna }\end{array}$ & $\begin{array}{l}\text { Funkcja } \\
\text { miasta }\end{array}$ & $\begin{array}{l}\text { Pow. } \\
\left(\mathrm{km}^{2}\right)\end{array}$ & $\begin{array}{c}\text { Populacja } \\
\text { (tys. mieszk.) }\end{array}$ & $\begin{array}{l}\text { Gęst. } \\
\text { zaludnienia } \\
\text { (tys. } \mathrm{km}^{2} \text { ) }\end{array}$ \\
\hline & 1 & 2 & 3 & 4 & 5 & 6 & 7 \\
\hline 1 & Indonezja & Surabaja & $\begin{array}{l}\text { cieśninia Madura } \\
\text { - wyspa Jawa }\end{array}$ & miasto portowe & 274 & 2766 & 10,010 \\
\hline 2 & Indonezja & Jogyakarta & $\begin{array}{l}\text { podnóże wulkanu } \\
\text { Merapi - wyspa } \\
\text { Jawa }\end{array}$ & $\begin{array}{l}\text { centrum } \\
\text { gospodarczo- } \\
\text { kulturalne kraju }\end{array}$ & 32,8 & 388,0 & 11,941 \\
\hline 3 & Malezja & Kuala Lumpur & $\begin{array}{l}\text { znaczne zróżnico- } \\
\text { wanie terenu }\end{array}$ & $\begin{array}{l}\text { stolica państwa } \\
\text { centrum gosp.bizn. }\end{array}$ & 243 & 1768 & 6,891 \\
\hline 4 & Singapur & Singapur & wyspa & miasto - państwo & 716,1 & 5607 & 7,797 \\
\hline 5 & Tajlandia & Bangkok & $\begin{array}{l}\text { delta rzeki Menam } \\
\text { (Chao Phraya) }\end{array}$ & $\begin{array}{l}\text { stolica państwa } \\
\text { centrum gosp.bizn. }\end{array}$ & 1569 & 9617 & 6,144 \\
\hline 6 & Tajlandia & Chiang Mai & tereny górskie & $\begin{array}{l}\text { hist. ośr adm. } \\
\text { regionu }\end{array}$ & 40,2 & 148,5 & 3,694 \\
\hline
\end{tabular}

\footnotetext{
5 W celu dokonania analizy porównawczej miast autor posługuje się krytyką literatury fachowej, oraz obserwacjami
} dokonanymi na miejscu, in situ”. 


\subsection{Kuala Lumpur}

Swój gwałtowny rozwój może zawdzięczać wyłączeniu z terytorium Malezji państwa Singapur, jako niezależnego. Od tego momentu dawne kolonie brytyjskie zaczęły pomiędzy sobą rywalizację o charakterze ekonomicznym, przemysłowym i terytorialnym. Pomimo wielu problemów podobnych dla wielkich miast (zatłoczone centrum, nierozwiązana komunikacja czy wielonarodowość), dziś jest to jedno z najnowocześniejszych i najszybciej rozwijających się miast azjatyckich.

Nieformalne centrum miasta to dzielnica - Kuala Lumpur Sentral, gdzie głównym ośrodkiem jest budynek dworca połączony z centrum handlowym. Plan KL Sentral obejmuje samowystarczalną koncepcję miasta, obejmującą wysokościowe budynki biurowe i biznesowe, międzynarodowe hotele, centra handlowe, wystawowe i kongresowo-konferencyjne. Obecnie wieżowce azjatyckie w swojej formie zainspirowane są sztuką, tradycją i kulturą krajów w których powstają, mają swój urok i są z pewnością rozpoznawalne [12].

Koncepcja urbanistyczna zakładała obudowę budynkami wysokościowymi głównej arterii komunikacyjnej na osi północ-południe. Projektant (Kisho Kurokawa \& Architects) tworząc to miejsce zakładał wykreowanie nowej wizji miasta globalnego - jako połączenie pracy, życia i zabawy w harmonijnym środowisku zbudowanym. Wyraził to poprzez stworzenie przestronnych placów, wewnętrznych dziedzińców w budynkach, kawiarni ulicznych, sklepów, restauracji i przejść dla pieszych przeplatającymi się z zielenią miejską. Taka przestrzeń publiczna miała harmonizować środowisko zbudowane wysokościowców z poczuciem natury i dostosowaną skalą człowieka.

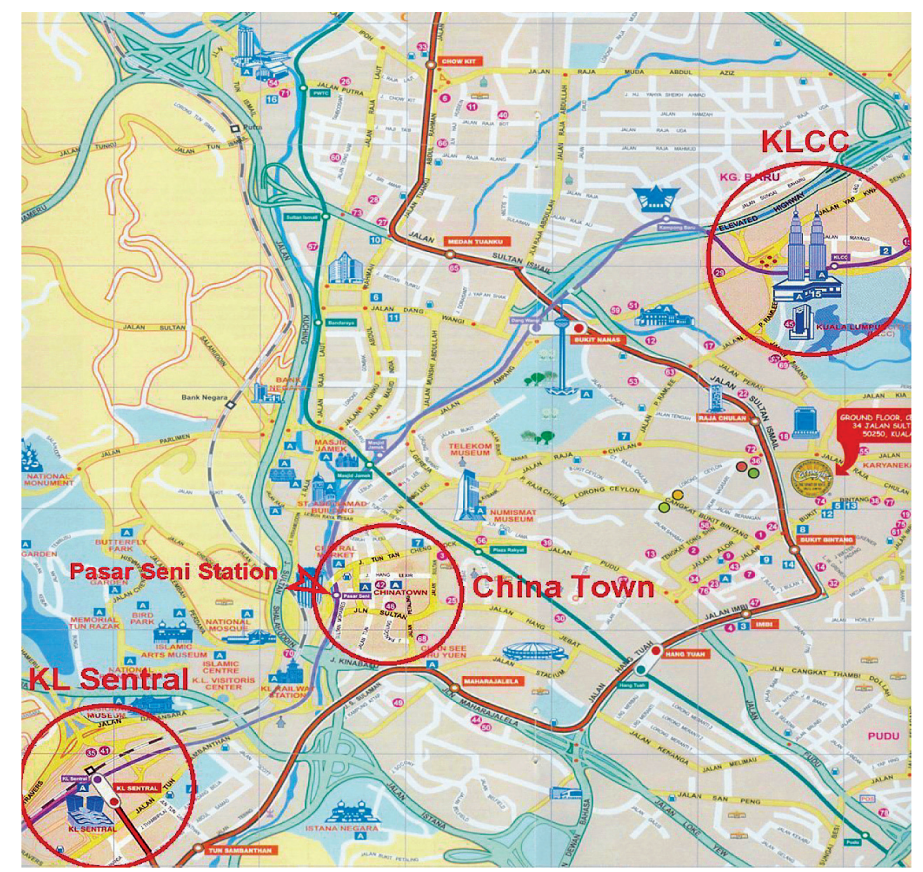

Fot. 1. Schemat układu przestrzennego centrum Kuala Lumpur. Legenda: Dzielnice: KL Sentral z głównym dworcem kolejowym (węzeł strategiczny miasta), China Town - dzielnica handlowa oraz KLCC - Kuala Lumpur City Center - nowoczesne centrum adm. - biurowe z symbolem miasta w postaci wież Petronas Towers, Komunikacja - niebieski - główne drogi kołowe, granatowy - linia kolejki KTM i metra LRT, czerwony - kolejka jednoszynowa Monorail 
Jeżeli kiedykolwiek zastanawialibyśmy się nad zdefiniowaniem budynku hybrydowaego - jako skrajnie wielofunkcyjnego, dworzec Sentral jest najlepszym tego przykładem. Oprócz dominującej funkcji komercyjnej mamy wiele kameralnych mikroprzestrzeni gastronomicznych. Jednak centralną wielopiętrową przestrzeń zajmuje kort tenisowy z widownią, oddzielony od innych funkcji przezroczystymi ściankami. Następuje tutaj również połączenie przestrzeni zewnętrznej otoczenia budynku z wnętrzem. Odbywa się to poprzez ruch wymianę potoków ludzi zmieniających środki transportu i kontynuujących podróże.

KL Sentral to przede wszystkim węzeł centralny. Jednak nie jedyny w tym mieście. O podobne miano rywalizują KLCC (Kuala Lumpur City Center) z nowoczesnym symbolem tego miejsca w postaci wież Petronas Towers, oraz China Town z odmienną niską dość chaotyczną przestrzennie i niejednorodną zabudową. Do niedawna istotną była lokalizacja centralna głównego dworca autobusowym Putra w podziemiu. Niespójne centrum miasta z wieloma węzłami strategicznymi i rozbudowaną wielopoziomową komunikacją kołową wydaje się organizować przestrzeń wokół nowoczesnych wysokościowców, czy to o charakterze biznesowym czy sakralnym, wielu meczetów (a dokładniej ich dominant - minaretów).
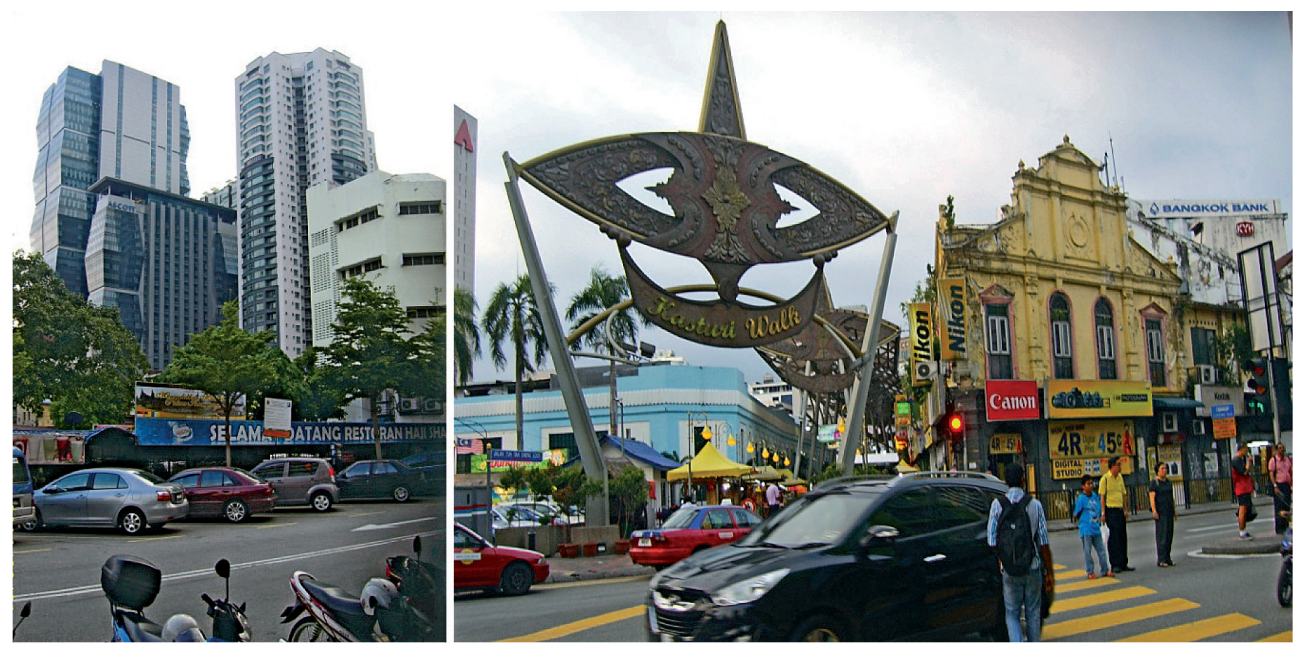

Fot. 2. Otoczenie nowoczesnych budynków

Fot. 3. China Town w Kuala Lumpur ze swoją niską i chaotyczną wielokulturową wysokich KL Sentral. Źródło: autor 2014 zabudową. Źródło: autor 2014

\subsection{Singapur}

Miejsce to uchodzi za miasto niezmiernie czyste, oczywiście jest to tylko wyobrażenie osób, które nigdy w nim tak naprawdę nie były. Miasto jest doskonale zorganizowane dzięki dyscyplinie i pracowitości swoich mieszkańców. Kolejną istotną rzeczą, która wyróżnia to małe miasto-państwo, jest dbałość o połączenie funkcjonalności i dostępności przestrzeni publicznej z jego wysoką kulturą architektoniczną projektowanych obiektów.

Singapur nie posiada wyraźnie zdefiniowanego centrum. Pomimo wielu punktów strategicznych nowoczesność wielokondygnacyjnych budynków miesza się tutaj z doskonale zachowanymi i zadbanymi budynkami kolonialnymi. Cechą charakterystyczną miasta jest również jego zwrócenie się w kierunku morza. Dzieje się to poprzez harmonijne zagospodarowanie 
nabrzeży oraz wprowadzenie wielu zielonych skwerów. To synergiczne działanie wpłynęło na wytworzenie mikroklimatu, wpływającego na przezwyciężenie uciążliwości klimatu równikowego.

Władze miejskie w ostatnich latach zdecydowały się na zmianę wizerunku metropolii, tworząc warunki do kreowania „Eko-miasta”. Większość działań ma na celu stworzenie spójnej wizji połączonych ciągów zieleni jako futurystyczne „miasto - ogród”. Najlepszym tego przykładem jest zagospodarowanie nieużytków w postaci 100ha cypla wcinającego się w morze na południowym zachodzie centrum. Powstałe w ten sposób tereny parkowe stały się znaną na całym świecie atrakcją, jako Marina Bay Gardens, ze stworzonymi „super drzewami” w postaci betonowo-roślinnych wież [4].

Kolejny policentryczny układ centrum wielkomiejskiego, wyróżnia się jednak niekonwencjonalnym rozwiązaniem. Polega ono na stworzeniu sieci punktów węzłowych pod ziemią. Ma to istotne znaczenie dla komfortu i dłuższego przebywania w tym klimacie. Pomijając same aspekty klimatyczne, węzły takie stanowią bezkolizyjny rozdział ruchu kołowego i pieszego, stając się szybkim sposobem dotarcia do poszczególnych obiektów w mieście połączonych z liniami kolejki metra.

Niespotykany nigdzie indziej na Dalekim Wschodzie przemyślany proces urbanistyczny kształtowania miast, polega na wykorzystaniu aspektów zrównoważonego rozwoju, poprzez połączenie rozwiązań proekologicznych ze świadomą partycypacją społeczną mieszkańców. Tego typu podejście stawia Singapur w szeregu państw innowacyjnych przystosowujących zdobycze naukowo-techniczne do potrzeb rozwoju przestrzennego.
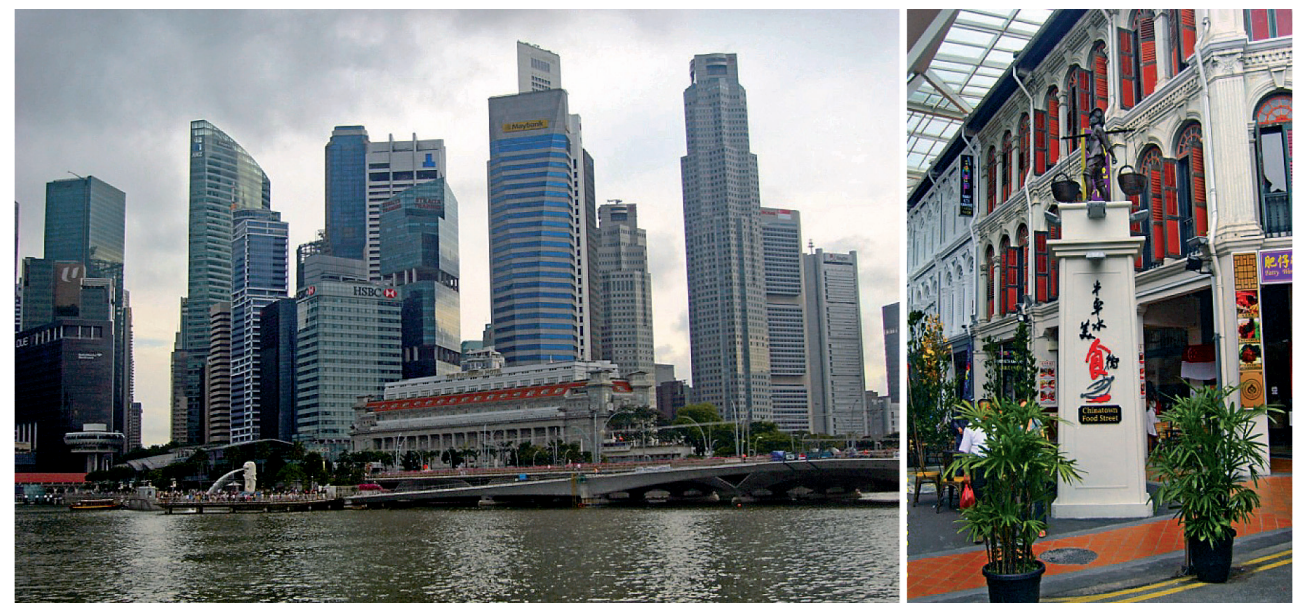

Fot. 4. Promenada wzdłuż wybrzeża morskiego - zabudowa wysoka centrum Singapuru

Fot. 5. Postkolonialna zabudowa China Town. Źródło: autor 2014 w Singapurze. Źródło: autor 2014

\subsection{Bangkok}

Jako typowy przykład miasta zdecentralizowanego, brak mu ściśle wyznaczonego centrum, które można uznać za najważniejsze miejsce. Mieszanie się niskiej zabudowy w dzielnicy turystycznej (okolice Khao San) z nowoczesnymi biurowcami (ulice Ratchadamri, Phaya Thai oraz Ramy I) powoduje poczucie chaosu i dezorientacji, dla nowo przybyłych do miasta turystów. 
O ile w większości dużych miast linia metra staje się elementem integracji poszczególnych dzielnic, o tyle w przypadku Bangkoku możemy mówić wyłącznie o połączeniu lotniska ze śródmieściem biznesowo-biurowym.

Samo centrum turystyczne z niską starą i wyeksploatowaną, spiętrzoną zabudową pozostaje dzielnicą funkcjonującą przede wszystkim w nocy. Gdzieś pomiędzy tymi nowoczesnymi wieżowcami a swego rodzaju gettem dla tłumów turystów i dzielnicą China Town zamyka się przestrzeń, którą można określić jako centrum miasta. Aby oddać specyficzny charakter tego miejsca należy jeszcze wspomnieć o kompleksie pałacowo - świątynnym sąsiadującym $\mathrm{z}$ terenami nadrzecznymi. Z uwagi na ogromne zatłoczenie samochodów na wszystkich śródmiejskich arteriach, rzeka wraz z siecią kanałów stała się dobrym i szybkim alternatywnym korytarzem komunikacyjnym dla mieszkańców. Nie trudno wyobrazić sobie chaos panujący w obrębie śródmieścia, towarzyszący mu tłum mieszkańców i turystów dopełnia obraz funkcjonowania tej wielomilionowej metropolii.

Chcąc określić miejsce przecinania się kierunków i sieci dróg w obrębie centrum należy powiedzieć o dworcu kolejowym Hua Lamphong. Jako znaczący obiekt kubaturowy o wymiarze historycznym stanowi on dominantę przestrzenną i istotny komunikacyjny węzeł przesiadkowy w obrębie miasta. Specyfika tego miejsca polega na jego randze i znaczeniu dla samych mieszkańców, ich miejscu pracy (maleńkich straganów rozlokowanych w okolicznych uliczkach) i walorach jako miejsca przecinania się arterii komunikacyjnych. Postępująca unifikacja i globalizacja sprawia iż przestrzeń publiczna wokół, staje się coraz częściej ograniczona i sprowadzona do wymiaru funkcji komunikacyjnej.
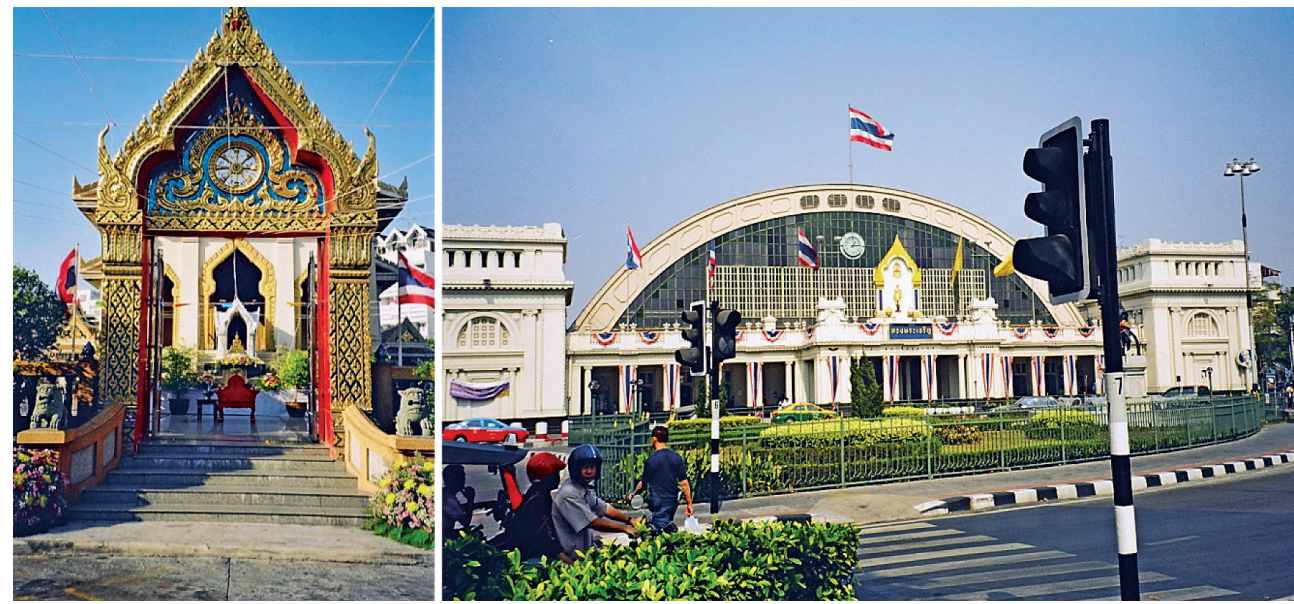

Fot. 6. W wielu miejscach architektura sakralna

Fot. 7. Okolice dworca kolejowego Hua Lamphong - punkt strategiczny Bangkoku miesza się z zabudową miejską. Źródło: autor 2004

\section{Podsumowanie i wnioski}

Przekonując się iż nie jesteśmy w stanie powstrzymać światowych procesów globalnych, w przypadku szeroko rozumianej globalizacji, gwałtownej urbanizacji czy podziałów wewnętrznych ośrodków w postaci metropolizacji, musimy szczególnie zadbać o jakość projektowanej i przebudowywanej przestrzeni publicznej. 
Niektórzy z architektów ${ }^{6}$ w swojej ocenie idą jeszcze dalej postrzegając procesy społeczne jako nieuchronne, rzutujące jednocześnie na przyszły rozwój ludzkości.

Punkty strategiczne przestrzeni miejskiej wielkich miast stają się wobec tych procesów elementami integracji struktury urbanistycznej wielkich ośrodków. Ciągłe przenikanie się przestrzeni miejskiej z nowoczesną architekturą wymusza zadawanie pytań o aspekt społeczny, przyszłego rozwoju centrów miast. Wartością dodaną (synergiczną) w organizacji przestrzeni współczesnych miast jest jej element kulturowy. Świadomość poczucia partycypacji społecznej na etapie projektowania z uwzględnieniem elementów kulturowych staje się fundamentalna dla rozwoju.

Tabela 2. Charakterystyka miejsc centralnych w przestrzeni publicznej wybranych miast azjatyckich (opracowanie własne)

\begin{tabular}{|c|c|c|c|c|c|c|}
\hline Lp. & Miasto & $\begin{array}{l}\text { Dzielnica } \\
\text { - kwartał }\end{array}$ & $\begin{array}{l}\text { Środowisko } \\
\text { zbudowane }\end{array}$ & Węzeł centralny & $\begin{array}{l}\text { Podstawowa } \\
\text { funkcja miejsca }\end{array}$ & $\begin{array}{l}\text { Uzupełniająca } \\
\text { funkcja miejsca }\end{array}$ \\
\hline 1 & $\begin{array}{l}\text { Kuala } \\
\text { Lumpur }\end{array}$ & SENTRAL & $\begin{array}{c}\text { zabudowa } \\
\text { wysoka } \\
\text { wysokościowa }\end{array}$ & $\begin{array}{c}\text { dworzec - jako obiekt } \\
\text { wielofunkcyjny } \\
\text { - dom handlowy }\end{array}$ & komunikacyjna & $\begin{array}{c}\text { centrum } \\
\text { administracyjno- } \\
\text {-biurowe }\end{array}$ \\
\hline 2 & Singapur & KALANG & $\begin{array}{l}\text { zabudowa } \\
\text { postkolonialna } \\
\text { zabudowa } \\
\text { wysokościowa }\end{array}$ & $\begin{array}{c}\text { nabrzeża } \\
\text { z kompleksem przejść } \\
\text { podziemnymi }\end{array}$ & $\begin{array}{l}\text { handlowo- } \\
\text {-rekreacyjna }\end{array}$ & $\begin{array}{c}\text { centrum } \\
\text { administracyjno- } \\
\text {-biurowe }\end{array}$ \\
\hline 3 & Bangkok & $\begin{array}{l}\text { PATHUM } \\
\text { WAN }\end{array}$ & $\begin{array}{l}\text { zróżnicowana } \\
\text { zabudowa niska } \\
\text { i wysokościowa }\end{array}$ & $\begin{array}{c}\text { dworzec } \\
\text { Hua Lamphong } \\
\text { - jako obiekt } \\
\text { wielofunkcyjny }\end{array}$ & komunikacyjna & $\begin{array}{l}\text { centrum } \\
\text { handlowe }\end{array}$ \\
\hline
\end{tabular}

Przebudowa i modernizacja przestrzeni publicznej centrów wielkich miast ciągle ewoluuje w kierunku zrównoważonego rozwoju przestrzennego, dzieje się to poprzez wiele czynników, takich jak:

- przeciwdziałanie suburbanizacji megalopolis, wraz z rozlewaniem się miast (urban sprawl), jako uzupełnianie zabudowy dzielnic biznesu budynkami o funkcji mieszkaniowej i usługowej,

- ukierunkowanie trendów miastotwórczych na wypróbowane i zdefiniowane idee zarządzania np. Eko-city, Smart-city czy Green-city, w celu uzyskania lepszych efektów poprawy warunków środowiska zamieszkania,

- uzupełnianie przestrzeni wznoszonych nowoczesnych obiektów wysokich i wysokościowych o elementy integracji z istniejącym środowiskiem zbudowanym, m.in. detal urbanistyczny, tworzenie mikroprzestrzeni relaksacyjnych (slow speace) czy obiekty ,street art”,

- przeciwdziałanie uniformizacji zabudowy centrów miast w warunkach światowej globalizacji odnoszącej się również do urbanistyki i architektury,

- dbałość o estetykę przestrzeni publicznej, wymuszoną poszukiwaniem i kreowaniem nowoczesnych obiektów kubaturowych, zintegrowanych z terenami zieleni,

6 ,powszechna globalizacja jest nieuchronna. Pojęcie globalizacji dotyczy przede wszystkim gospodarki, ale także architektury jako sztuki twórczego kształtowania środowiska. Przemierzając świat wciąż da się zauważyć podobne założenia urbanistyczne, zbliżone kształtowanie elewacji, czy użycie identycznych materiałów”. [7] s. 98 
- zapewnienie odpowiednich proporcji w kreowaniu i rewitalizowaniu przestrzeni miejskiej, w celu podkreślenia cech historycznych i kulturowych miejsc.

Adekwatne wydają się stwierdzenia ${ }^{7}$ podkreślające znaczenie we współczesnej urbanistyce przestrzeni publicznych, z podkreśleniem jej społecznego charakteru. Człowiek wraz z otoczeniem jakie tworzy poprzez kulturę sztukę i przyrodę tworzy zintegrowane środowisko miejskie, przystosowane do swoich potrzeb.

Wielu współczesnych planistów postrzega kształtowanie nowoczesnych miast w warunkach zrównoważonego rozwoju, w kategoriach działań integracyjnych polityki ekspansji miast i regionów, a także kompleksowego zarządzania rozwojem obszarów metropolitarnych. Na podstawie przytoczonych przykładów i konkluzji nn pracy można z całą pewnością stwierdzić iż są to działania niewystarczające.

\section{Literatura}

[1] Chmielewski J.M. Teoria urbanistyki w projektowaniu i planowaniu miast. Oficyna Wydawnicza Politechniki Warszawskiej. Warszawa 2001.

[2] Cieśla S. Globalizacja i metropolizacja. Niektóre aspekty badań polskiej przestrzeni. Studia Regionalne i Lokalne 4(4) 2000, Uniwersytet Warszawski, Warszawa 2010.

[3] Dymnicka M. Fragmentaryzacja przestrzeni publicznej - próby rekompozycji. Studia Regionalne i Lokalne 3(33) 2008, Uniwersytet Warszawski, Warszawa 2001.

[4] Gaweł D. Zielone przestrzenie publiczne czy parki? Współczesne tendencje ksztattowania terenów rekreacyjnych miast. Współczesne miasto jako środowisko życia człowieka zintegrowane z przyrodą, red. St. Wehle-Strzelecka, Monografia 2. Seria Architektura. Politechnika Świętokrzyska, Kielce 2015.

[5] Gaweł D. Synergia w ekonomii, jako czynnik miastotwórczy w Chinach. Budownictwo i Architektura 16(1) (2017).

[6] Giddens A. Socjologia. Państwowe Wydawnictwo Naukowe, Warszawa 2004.

[7] Gronostajska B.E. Kształtowanie wspótczesnych osiedli mieszkaniowych, globalizacja czy regionalizacja. Czasopismo Techniczne 107(7) (2011).

[8] Jałowiecki B. Metropolie. Białystok 1999.

[9] Krier L. Architektura wybór czy przeznaczenia. Arkady. Warszawa 2001.

[10] Lynch K. The image of the City. The MIT Press, Cambridge:1960.

[11] Nowicki J. Ksztalt przestrzeni mieszkalnej. Zakład Wydawnictw CZSR, Warszawa 1980.

[12] Pawłowski A.Z., Cała I. Budynki wysokie. Oficyna Wydawnicza Politechniki Warszawskiej. Warszawa 2013.

[13] Smith R.G. Mongrel globalization. Speace and culture 8(1) (2005).

[14] Węcławowicz G. Geografia społeczna miast. Wydawnictwo Naukowe PWN. Warszawa 2001.

[15] Wejchert K. Elementy kompozycji urbanistycznej. Arkady. Warszawa 1984.

[16] Zuziak Z.K. Strategiczne węzły przestrzeni przepływów. Czasopismo Techniczne 108(10) (2011).

\footnotetext{
7 „neoliberalna logika rozwoju miasta uznaje zasadę spontaniczności w miejscach, gdzie dominują interesy grup dużego kapitału, spychając na margines jedno z ważniejszych zadań współczesnej urbanistyki - ochronę i rozwój przestrzeni publicznej. W związku z kryzysem, jaki obecnie przechodzi (presja komercji), podejmuje się próby przywracania jej znaczenia społecznego i przestrzennego. Celem przeobrażeń jest powiązanie przestrzeni publicznych z szerszym otoczeniem (z terenami otwartymi, strefami nadwodnymi, ciągami spacerowymi, placami zabaw etc.)." [3] s. 33.
} 


\title{
Strategic urban nodes in the big cities of South-East Asia
}

\author{
Dariusz Gawel \\ Independent Laboratory of Architecture, Faculty of Civil Engineering and Architecture, \\ Lublin University of Technology, e-mail: d.gawel@pollub.pl
}

\begin{abstract}
This article addresses the problem of shaping public spaces within fastemerging neighborhoods and new buildings in major South-East Asian cities. Nowadays, the creation of new urban trends has been reduced in Europe (where the revitalization process is still leading), moving to Asia where huge new neighborhoods and cities are being created in our eyes (often violently and rapidly). The problems discussed in the article relate both to the way of shaping the structure of public spaces of big cities, including new urban phenomena emerging from the background of known and diagnosed phenomena such as metropolization or globalization. Strategic elements of the metropolitan structure of large Asian cities are often contributing to the creation of new independent districts - regions that affect the division and fragmentation of the public space itself, and consequently the isolation of independent centers.
\end{abstract}

Keywords: strategic nodes, public space, big cities, South - East Asia, metropolization, globalization. 